\title{
AUDIÇÃO RADIOFÔNICA EM UMA COMUNIDADE RURAL NA AMAZÔNIA PARAENSE B'
}

\author{
Manoel Ednaldo Rodrigues²
}

\section{RESUMO}

O enfoque deste artigo foi investigar a importância do rádio no cotidiano dos moradores de Vila Brasil, no Rio Arapiuns, em Santarém - Pará, observando a experiência do projeto de alfabetização de adultos, do Movimento de Educação de Base (MEB), no período de 1966 a 1985. A construção teórica e metodológica teve como base os estudos culturais latino-americanos e de recepção propostos por Martín-Barbero e discutido também por García-Canclini e Guillermo Orozco, com direcionamento teórico ao estudo da comunicação. Partindo das contribuições desses pesquisadores e de autores brasileiros: Ana Carolina Escosteguy, Nilda Jacks, Mauro Wilton de Sousa e Sônia Virgínia Moreira discutiu-se a noção de audição radiofônica em uma comunidade rural na Amazônia paraense. Identificou-se, ao final, que o rádio começou a perder espaço para a televisão e ao progresso. A chegada da energia elétrica provocou mudanças que aos poucos vão sendo percebidas. A energia elétrica se tornou uma forte aliada da TV, mas não afetou só o rádio, os mais velhos também estão perdendo o hábito de contar estórias aos mais jovens no início da noite. As pessoas deixaram o hábito de levar o rádio ao roçado e à pescaria, porque os que funcionavam à base da pilha estão sendo substituídos por aparelhos à energia elétrica. Enfim, o rádio ainda possui importância relevante aos radiouvintes de Vila Brasil, integrando a rotina do dia a dia da comunidade, mesmo considerando a presença de outros suportes de mediações.

Palavras-chave: Audição. Rádio. Comunidades rurais. Amazônia paraense. Comunicação.

\section{RADIOBROADCAST HEARING IN A RURAL COMMUNITY IN THE PARAENSE}

\section{AMAZON}

\section{ABSTRACT}

The aim of this article was to investigate the importance of radio in the daily lives of the residents of Vila Brazil, in the Arapiuns River, in Santarem - Pará, observing the

1 Este artigo tem origem na pesquisa de Dissertação de Mestrado em Ciências da Comunicação - UFPA, Belém, Pará, 2014, sob a orientação da Profa. Dr ${ }^{a}$. Netília Silva dos Anjos Seixas.

2 Mestre em Ciências da Comunicação na Universidade Federal do Pará - UFPA - 2014. Email: ednaldorodrigues@hotmail.com 
experience of the adult literacy project of the Basic Education Movement (MEB) from 1966 to 1985. The theoretical and methodological construction of the research was based on the Latin American and reception cultural studies proposed by MartínBarbero discussed also by García-Canclini and Guillermo Orozco, with a theoretical orientation to the study of communication. It was discussed the notion of radiobroadcast hearing in a rural community in the Amazon region of Pará based on the contributions of these researchers and the Brazilian authors: Ana Carolina Escoste guy, Nilda Jacks, Mauro Wilton de Sousa and Sônia Virginia Moreira. It was eventually identified that radio began to lose space for television and progress. The arrival of electric power has brought about changes that are gradually being perceived. Electric power has become a strong ally of TV, but it has not only affected the radio listening, the older ones are also losing the habit of telling stories to younger people in the early evening. People have lost the habit of taking the radio to the ground that has been brushed to be cultivated and the fishery, because the radios that work on batteries have being replaced by appliances with electricity. Finally, the radio still has relevant importance to the listeners of Vila Brazil, integrating the routine of the day by day of the community, even considering the presence of other supports of mediations.

Keywords: Hearing. Radio. Rural communities. Amazon Pará. Communication.

\section{AUDIENCIA RADIOFÓNICA EN UNA COMUNIDAD RURAL EN LA AMAZONIA}

\section{PARAENSE}

\section{RESUMEN}

El enfoque de este artículo fue investigar la importancia de la radio en el cotidiano de los habitantes de Vila Brasil, en el Río Arapiuns, en Santarém - Pará, observando la experiencia del proyecto de alfabetización de adultos, del Movimiento de Educación de Base (MEB) 1966 a 1985. La construcción teórica y metodológica tuvo como base los estudios culturales latinoamericanos y de recepción propuestos por Martín Barbero y discutido también por García Canclini y Guillermo Orozco, con dirección teórica al estudio de la comunicación. A partir de las contribuciones de estos investigadores y de autores brasileños: Ana Carolina Escosteguy, Nilda Jacks, Mauro Wilton de Sousa y Sonia Virginha Moreira, se discutió la noción de audición radiofónica en una comunidad rural en la Amazonia paraense. Se identificó, que la radio comenzó a perder espacio en pos de la televisión y el progreso. La llegada de la energía eléctrica provocó cambios que poco a poco se fueron percibiendo. La energía eléctrica se ha convertido en una fuerte aliada de la televisión, pero no ha afectado sólo a la radio, los mayores también están perdiendo el hábito de contar historias a los más jóvenes a primera hora de la noche. Las personas dejaron el hábito de llevar la radio al rozado y a la pesca, porque las radio a pila está siendo reemplazada por aparatos a energía eléctrica. En fin, la radio todavía tiene importancia relevante para los radio oyentes de Vila Brasil, integrando la rutina del día a día de la comunidad, aún considerando la presencia de otros soportes de mediaciones.

Palabras clave: Audición. Radio. Comunidades rurales. Amazonia paraense. Comunicación. 


\section{INTRODUÇÃO}

Este artigo teve como motivação inicial a inquietação sobre o papel do rádio no passado e no presente das comunidades rurais, buscando maior aprofundamento para compreender as recorrentes afirmações sobre as diversas funções que esse meio de comunicação exerce ou exerceu aos radiouvintes da região, no interior da Amazônia.

A pesquisa foi realizada em Vila Brasil, comunidade interiorana, no município de Santarém, Pará, ambiente próprio da Amazônia, reunindo potenciais diversos em uma única localidade, com base na corrente dos estudos culturais latino-americanos.

A organização espacial de Vila Brasil, de acordo com Santos (2010), apresenta três núcleos principais: a) o núcleo comunitário, no qual está presente, além das casas, a infraestrutura comunitária; b) o lago comunitário e o rio, nos quais se concentra a atividade pesqueira; c) as áreas de terra firme, nas quais se distribuem capoeiras em diferentes estágios de recomposição, roçados familiares e reservas florestais.

A comunidade de Vila Brasil está localizada em Santarém, à margem direita do Rio Arapiuns, distante da sede do município a cinco horas de barco. Formada por 85 famílias, foi fundada em 1958 por Guilherme Dourado, comerciante que se instalou e se tornou morador do lugar. 0 Entrevistado, BFS, 74-M, revelou que nome da Vila é uma homenagem ao Brasil, devido à abundância das belezas naturais peculiares do Rio Arapiuns, especialmente a fauna e a flora. Entre outras bases econômicas estão à pesca, o artesanato e a agricultura.

Sobre a presença do rádio, destaca-se que esse meio de comunicação se transformou em um serviço social, transmitindo música, informação e entretenimento. Tudo isso e outras utilidades do rádio converteram-se em objetivos dos idealizadores de uma das emissoras de rádio local, a Rádio Rural de Santarém AM, em relação à educação e à cultura, ou seja, de utilizar o veículo para alfabetizar as pessoas, no interior do município. Esse trabalho de alfabetização seria mediado por programas radiofônicos específicos. 
No início da década de 1960, surgiu um grande movimento que viria a utilizar o rádio como suporte para alfabetizar os adultos. $\bigcirc$ projeto entraria para a história com a denominação de Movimento de Educação de Base (MEB). Sônia Virgínia Moreira (1998, p.72) afirma que "O MEB atingiu seu ponto máximo em 1964. Naquele ano, mobilizava 25 emissoras e 54 sistemas de transmissão, a maioria nas regiões Norte/Nordeste".

O MEB foi encampado, na Amazônia, pela Rádio Rural de Santarém AM, emissora católica que alimentava o sonho de educar as pessoas por meio desse suporte de comunicação. Segundo a professora Aurenice Gabler (2017), que coordenou o MEB em Santarém, no período de 1974 a 1985 foi idealizada a Feira da Cultura Popular, evento cultural criado como estratégia para motivar $O$ envolvimento das comunidades rurais e $O$ consequente interesse pelos programas educativos. Em Santarém, O MEB iniciou suas atividades em 1966 e, a partir de 1969, as comunidades se reuniam na cidade para apresentar um resumo de sua produção agrícola e cultural, dando origem a uma feira de exposição e uma gincana com a participação das escolas do interior, motivados pela Rádio Rural.

Considerando esse contexto, esta pesquisa pretende responder: quais os atores sociais que participaram das aulas radiofônicas do MEB? Como monitores e alunos avaliam esse projeto de educação? Quais os resultados alcançados pelos programas de rádio do MEB? Havia diferença entre o MEB e outros projetos de alfabetização pelo rádio?

O artigo está estruturado da seguinte maneira: primeiramente, apresenta uma aproximação dos estudos culturais e de recepção por meio de um cenário da pesquisa sobre esses conceitos, bem como os meios de comunicação de maior preferência, com uma nova perspectiva teóricometodológica na América Latina e em especial no Brasil. Na sequência, o percurso metodológico, bem como, os procedimentos da pesquisa para se atingir os objetivos propostos; depois se faz uma viagem por Vila Brasil, destacando os seus aspectos geográficos, econômicos, culturais e sociais a fim de obter uma compreensão mais ampliada sobre a realidade local. Finalmente, apresentam-se os resultados e a discussão sobre a audição 
radiofônica em Vila Brasil, quando se constata que o rádio ainda mantém importância relevante aos comunitários, mesmo dividindo a audiência com outros meios, como o celular, a televisão e outros recursos tecnológicos da atual modernidade.

\section{VILA BRASIL E SEUS ASPECTOS GERAIS}

Aqui, faz-se uma viagem, observando o contexto histórico-geográfico, econômico-social e cultural, assim como a atual organização institucional do local onde a pesquisa foi realizada. Uma comunidade rural que também sofreu as influências das mudanças ocorridas nos últimos em todo o mundo.

De acordo com Castells (1999), o mundo mudou, desfazendo-se da estratificação vertical que caracterizaria o estado das coisas no mundo o qual conhecíamos até pouco tempo atrás, rumo a uma tendência de horizontalidade nas relações sociais, econômicas e culturais entre os homens.

\footnotetext{
Uma revolução tecnológica concentrada nas tecnologias da informação está remodelando a base material da sociedade em ritmo acelerado. Economias por todo o mundo passaram a manter interdependência global, apresentando uma nova forma de relação entre a economia, o Estado e a sociedade em um sistema de geometria variável (CASTELLS, 1999, p. 21).
}

Em se tratando da Amazônia, compreende-se que a região também esteja em processo de mudança. A revolução tecnológica que assolou o mundo desenvolvido, aos poucos também chega às comunidades amazônicas, mesmo aos lugarejos mais distantes. Refletindo no modo de viver e no jeito de agir, postura e no comportamento de homens e mulheres nas cidades e no interior de uma Amazônia, às vezes vista inerte, congelada no tempo e no espaço.

A história da comunidade de Vila Brasil também está relacionada com as comunidades dos rios Tapajós, Arapiuns e Lago Grande e antecede a chegada do europeu à Amazônia. Trata-se de um relato que remonta há séculos, difícil de sintetizar. Embora já existisse uma organização social dos povos que já habitavam a região muito antes da chegada dos portugueses 
e de outros povos, a história oficial, no entanto, considera como ponto de partida a chegada do colonizador à região amazônica.

Outro desafio é a carência de estudos aceitos ou produzidos pela academia voltados para a região, específicos sobre recepção, capazes de amparar as informações que são repassadas oralmente, uma das práticas de transmissão cultural dos povos da Amazônia.

Nesse aspecto, nesta pesquisa, percebe-se que os moradores mais antigos, tornam-se atores e autores de sua própria história, que inicia pelo nome do lugar, que, segundo o Entrevistado 1, 74-M, foi denominado Uxicará. Trata-se de um neologismo criado a partir da junção das palavras de origem indígena Uxi e Cará. Uxi é uma fruta silvestre e Cará um legume: ambos são abundantes na região amazônica e, em especial, no Arapiuns.

De acordo com o Entrevistado 2, 83-M, reforçado pelo depoimento de moradores mais antigos, a mudança de nome de Uxicará para Vila Brasil se deu no dia 20 de fevereiro de 1958, após a primeira missa celebrada pelo franciscano Frei Graziano, quando foi realizada uma assembleia geral, com a participação dos moradores. Naquela ocasião ficaram definidos pelos católicos da comunidade os dias $1^{\circ}$ e 2 de agosto do mesmo ano para celebrar as festividades, dedicadas a Nossa Senhora Rainha, que passou a ser a padroeira de Vila Brasil, sendo a imagem doada pelo celebrante.

O lugar passou a ser conhecido com esse novo nome a partir da implantação da Igreja Católica, construída em forma de puxirum³ pelos moradores da época, motivados pelo comerciante José Guilherme Dourado, considerado como o fundador da comunidade.

O Entrevistado 2, 83-M conta como o fundador de Vila Brasil trabalhou para organizar os primeiros passos do lugar: Dourado, que ficou conhecido por Nazinho, apareceu na região do Arapiuns como comerciante,

\footnotetext{
${ }^{3}$ Palavra que significa trabalho em comum. É o trabalho coletivo, em geral na roça de uma família, a cada dia, de forma que todas as famílias vão trabalhando em todas as roças do povoado. Os puxiruns são ocasião de trabalho e de festa também. Os moradores comem, trabalham, bebem e até dançam juntos (FERREIRA, 1999).
} 
trabalhando em um regatão 4 . Ele vendia produtos secos e molhados, remédio, tecidos e comprava dos moradores toda a produção que havia: farinha puba, farinha tapioca, paneiros de Uambé, tipiti de tala de buriti, peneiras de arumã, madeira, látex e sernambi. Além disso, distribuía cartazes com a imagem de Nossa Senhora Terezinha.

De acordo com o Entrevistado 2, 83-M, ao chegar a Uxicará, Guilherme Dourado construiu casa própria, instalou um comércio e aos poucos foi conquistando a confiança e a amizade dos moradores da região. Ele atuava como comerciante em várias comunidades do Rio Arapiuns e do Lago Grande e logo conquistou a simpatia dos habitantes, pois se tratava de uma pessoa muito agradável e esclarecida.

Em se tratando da economia da comunidade, as bases econômicas são agricultura, pesca, artesanato e extrativismo vegetal. Os produtos artesanais mais destacados são chapéus, bolsas, cestas, garrafas, porta-joias, cuias e peneiras. Além disso, Vila Brasil conta com potencial turístico formado por rios, igarapés, paisagens e florestas.

Para os pesquisadores Adams, Murrieta e Neves (2006, p. 281), na Amazônia, "cada atividade possui um padrão distinto ao longo do ano, que envolve diferentes membros da unidade familiar e preenche funções diferenciadas na economia doméstica".

Atualmente, a produção com maior escala em Vila Brasil é a farinha de mandioca, que contribui com a economia da comunidade. Além de outros produtos, especialmente os extrativistas, provenientes das coletas que se tornaram conhecidas como Drogas do Sertão5, a cada dia ficam mais escassos.

O representante dos trabalhadores, Entrevistado 15, 47-M, destacou que, em Vila Brasil, as culturas mais populares são a mandioca, o milho, o cupuaçu e o açaí. A partir da mandioca, os agricultores extraem farinha, tapioca, beiju, tucupi e outros derivados. Na região do Arapiuns, Vila Brasil é

4 O regatão tinha a função de casa aviadora, mas era também um barco, meio de transporte e outras funções, como "correio" (FERREIRA, 2009).

5 Produtos obtidos por atividade extrativa no Brasil colonial: cacau, canela, castanha, cravo, pimenta etc. (FERREIRA, 1995).

Revista Exitus, Santarém/PA, Vol. 9, № 1, p. 340 - 366, JAN/MAR 2019. 
a comunidade que está cultivando o plantio de açaí e a extração é feita por meio de manejo. Atualmente (2013), os açaizais nativos praticamente não existem mais, mas há açaí em abundância, resultado do projeto de manejo que iniciou há algum tempo. As culturas mais abundantes são a mandioca e o milho: o plantio da mandioca é praticado entre os meses de novembro a fevereiro, e a colheita se dá entre doze e dezoito meses; o milho é cultivado entre os meses de novembro e dezembro, e a colheita é feita entre os meses de abril e maio.

Os pescadores de Vila Brasil têm à disposição um rio caudaloso que proporciona peixe em abundância na época da piracema, que se manifesta nos meses de janeiro, abril, maio, setembro e outubro, com diversas espécies, sendo o Jaraqui aquele que registra maior população. Para o Entrevistado 7, 63-M, no restante dos meses, o peixe fica mais escasso e mais distante da vila, devido ao verão, quando parte do rio fica seco.

Os agricultores trabalham nas roças. Como a vila cresceu bastante, passaram a fazer os seus cultivos em terrenos mais afastados do núcleo da comunidade. Os locais dos roçados são chamados de centro, que se localiza a longas distâncias, à uma hora de caminhada em relação ao núcleo de Vila Brasil, em média, típico das sociedades não urbanas:

\begin{abstract}
As sociedades "não urbanas" contemporâneas da Amazônia podem ser divididas, grosso modo, em sociedades indígenas; camponeses (tradicionais) ou históricos (caboclos), oriundos da incorporação colonial da região Amazônica; e os neocamponeses que, desde a década de 1970, tem migrado como parte das políticas governamentais de ocupação da Amazônia (ADAMS; MURRIETA; NEVES, 2006, p. 15).
\end{abstract}

A partir de 2010, a comunidade de Vila Brasil recebeu a estrada que dá acesso ao município de Juruti, no oeste do Pará. Com isso, alguns agricultores mais aquinhoados economicamente adquiriram motocicletas, o que Ihes possibilitou reduzir bastante o tempo de viagem. Antes eles demoravam até uma hora de caminhada entre os roçados e o núcleo da comunidade, mas, com a introdução das motocicletas, o tempo caiu para quinze minutos. Ainda são poucos os agricultores que possuem esse tipo de 
veículo; a maioria ainda caminha a pé para chegar às roças. Aqui ficam evidentes as características da hibridação cultural, conceito discutido por Canclini (1993):

Entendo por hibridação processos socioculturais nos quais estruturas ou práticas discretas, que existiam de forma separadas, se combinam para gerar novas estruturas, objetos de práticas. Cabe esclarecer que as estruturas chamadas discretas foram resultados de hibridações, razão pela qual não podem ser consideradas fontes puras (CANCLINI, 1993, p. 19).

A introdução de uma nova estrutura faz com que os costumes de uma comunidade rural, entre outros aspectos, aos poucos sofram um processo de urbanização. Com o passar dos anos, percebem-se características do rural e do urbano em um mesmo espaço. Com isso, os moradores criam novos hábitos, resultantes da hibridação cultural.

Nesse aspecto, Vila Brasil apresenta as mesmas complexidades das comunidades amazônicas: a trajetória e a consequente sedimentação dos valores e dos hábitos culturais das populações que habitam essas regiões. A discussão principal se volta à cultura de comunidades de rios e à religiosidade dos moradores do lugar. Os moradores de Vila Brasil são pequenos agricultores e parte da população descende dos primeiros ocupantes, perdidos na imensidão das florestas do Arapiuns.

O processo de colonização da região amazônica foi longo. A política colonial visava sempre à expansão de território à coroa portuguesa e, como a região sempre esteve povoada, principalmente no litoral, um dos métodos adotados foi de expulsar os nativos, como afirma IORIS (2005):

A massiva participação daquela população indígena recém-saída das políticas coloniais tornou-a alvo central das forças de combate e da repressão que se seguiu, cujas ações fizeram perecer larga parcela desses indígenas e causaram intensos movimentos de fugas, que deixaram esvaziadas as terras ao longo das margens do Tapajós (IORIS, 2005, p. 227).

Embora a autora faça referência à região do Tapajós, não se pode deixar de refletir que a região do Arapiuns forma um paralelo. Percebe-se que os atuais moradores fixados ao longo do litoral do Arapiuns têm 
parentesco com os nativos do Tapajós. Além disso, apresentam uma nítida mistura étnica, com as mesmas características do homem da Amazônia atual. Para Rodrigues (2013, p. 43), esse fenômeno pode ser compreendido devido ao choque cultural que a região sofreu com o processo de ocupação, com a vinda do colonizador europeu e, mais tarde, com a vinda em massa dos migrantes nordestinos.

Outro tema importante que integra a cultura de Vila Brasil é a religiosidade dos comunitários, que se dividem entre evangélicos e católicos. Os católicos são em maior número. Eles elegeram como padroeira Nossa Senhora Rainha.

Atualmente (2013), as festividades são realizadas na segunda semana de agosto. A festa religiosa rende homenagens à padroeira, mobilizando as comunidades mais próximas. Durante os dias de festa, os comunitários/visitantes têm participação especial, transformando o pequeno lugar em um arraial. 6

Os moradores de Vila Brasil, de tempo em tempo, realizam as suas festas religiosas para revitalizar a fé e revigorar as práticas cotidianas, desgastadas, como já observou antes Martín-Barbero (2006), em outro contexto, a respeito das festas.

\begin{abstract}
A festa não se constitui, contudo, à cotidianidade; é, antes, aquilo que renova o seu sentido, como se a cotidianidade se desgastasse e periodicamente a festa viesse a recarregá-la novamente no sentido de pertencimento à comunidade (MARTíN-BARBERO, 2006, p. 142).
\end{abstract}

Em Vila Brasil, os sinais da religiosidade estão presentes na tradição do povo. Os comunitários mantêm a imagem da Santa na Igreja da comunidade e em determinados momentos, quando se sentem ameaçados por algum fenômeno natural, fazem suas promessas, preces e devoções.

De acordo com Rosendahl (2001), a devoção aos santos é expressão do catolicismo popular, principalmente em áreas rurais, onde a presença oficial da igreja não é constante. A privatização do sagrado se expressa pela

\footnotetext{
${ }^{6}$ Lugar onde se juntam romeiros, onde há tendas provisórias, barracas com produtos comestíveis, jogos e diversões, com ornamentação, música, etc. (FERREIRA, 1999).
}

Revista Exitus, Santarém/PA, Vol. 9, № 1, p. 340 - 366, JAN/MAR 2019. 
relação do homem religioso com o sagrado, sem a intervenção de nenhuma mediação institucional entre eles. É uma prática que se dá nas comunidades rurais onde as igrejas passam a ser administradas pela própria comunidade, com ajuda das pessoas mais aquinhoadas economicamente.

Dessa forma, os moradores de Vila Brasil fundamentam a fé e mantêm um costume típico das comunidades rurais amazônicas, que se dá pela religiosidade e pelos hábitos culturais. A comunidade também se torna mediadora por meio de suas instituições na área social ou religiosa, ao transmitir para outras gerações os costumes sedimentados historicamente.

\title{
Aproximação dos estudos culturais e de recepção
}

No Brasil e na América Latina, os temas mais frequentes sobre os estudos culturais e de recepção versam sobre a televisão, depois sobre o rádio e, por último, sobre o impresso. Lopes (1993) afirma que os estudos culturais latino-americanos de recepção iniciam a partir de 1980, com uma nova perspectiva teórico-metodológica. Esse esforço tem como finalidade superar as limitações epistemológicas dos estudos em relação aos modelos anteriores como da pesquisa dos efeitos, de audiência e de usos e gratificações, da crítica literária e dos Estudos Culturais de matrizes inglesas, como explica:

\begin{abstract}
A problemática da recepção, nesta orientação, busca uma (re) formulação teórico-metodológica, que propõe organizar as tentativas interdisciplinares e de multi-métodos numa malha teórica compreensiva, respondendo as demandas de complexidade e de crítica, tendo em vista a atual conjuntura da pesquisa internacional nesta área do conhecimento (LOPES, 1993, p. 43).
\end{abstract}

Esta pesquisa também vai destacar Mauro Wilton de Sousa, organizador do livro Sujeito, o lado oculto do receptor, resultado de um seminário realizado em 1991, na Escola de Comunicação e Artes da Universidade de São Paulo. Para Sousa (1995), as pesquisas de recepção encontram um campo propício nos Estudos Culturais, deslocamentos e rupturas metodológicas. Em relação à recepção trazem novo sentido e categorias explicativas como as referidas entre cultura e ideologia, 
negociação e dominação, cotidianas e sistema social. Dessa forma, constituise num campo de problemáticas que possibilitariam um novo olhar sobre as práticas dos estudos de recepção:

Outras pistas daí advêm igualmente. Retomar os estudos culturais como eixo nos estudos de recepção midiática e confrontá-los com aqueles que buscam atualizar o debate sobre a esfera pública contemporânea do pensamento político e social, traz novos vetores de aproximação entre cultura, comunicação e política. A indicação de possibilidades de espaços públicos, parciais, fragmentados, e onde demandas sociais ganham significação, frente àqueles da representação política, faz reintroduzir a comunicação, não mais como elemento de deterioração do espaço público pela sua vinculação mercadológica, mas como espaço de mediação no conflito das sociedades democráticas emergentes (SOUSA, 1995, p. 46).

As pesquisadoras Ana Carolina Escosteguy e Nilda Jacks (2005), por meio de um estudo que fez um diagnóstico sobre a pesquisa de recepção no Brasil a partir de 1990, constataram que os principais teóricos são do continente latino-americano:

A partir da pesquisa realizada sobre os estudos de recepção no Brasil, a maioria das dissertações e teses fundamenta-se nos seguintes autores: 23 de 36 escolheram entre Martin-Barbero, Canclini e Orozco, sendo que dessas 23, 19 vinculam-se a Martin-Barbero como o autor principal ou articulado a outro. Percebe-se, assim, a predominância dos três autores sobre os demais e a larga influência de MartínBarbero (ESCOSTEGUY, JACKS, 2005, p. 90).

Jesús Martín-Barbero é espanhol, mas reside na Colômbia desde 1963. Os seus principais estudos, entre os quais o das mediações, foram realizados na América Latina. Néstor García-Canclini é argentino e Guillermo Orozco Gómez é mexicano (ESCOSTEGUY, JACKS, 2005). Com o livro Dos meios às mediações, Martín-Barbero provocou o deslocamento dos estudos, contribuiu com a descoberta do receptor e com os avanços das pesquisas comunicacionais. O foco do objeto de estudo, que antes era voltado aos meios, com as novas possibilidades de análise, voltou-se para as mediações. Para Martín-Barbero (2006), de passivo o receptor passou a ativo, e observase que o receptor produz sentido, se apropria e faz usos das mensagens recebidas. 
Para Escosteguy e Jacks (2005), ao contrário da recepção na teoria dos usos e gratificações, que trabalhava com o conceito de massa, a recepção nos estudos culturais, com base no conceito de mediações, de Martín-Barbero (2006), possibilitou aprofundar a complexidade da recepção, um dos maiores diferenciais dos estudos dos anos 1990, ou seja,

O eixo do debate deve se deslocar dos meios para as mediações, isto é, para as articulações entre práticas de comunicação e movimentos sociais, para as diferentes temporalidades e para a pluralidade das matrizes culturais (MARTíN-BARBERO, 2006, p. 258).

Trata-se de um deslocamento da análise do meio propriamente dito para onde o sentido é produzido, para o âmbito dos usos sociais, as mediações culturais da comunicação. A recepção como objeto de estudo transforma-se também em um lugar para investigação. Nesse sentido, com relação aos estudos propostos pela teoria das mediações, Martín-Barbero explica como ocorre esse deslocamento, de acordo com a proposta dele:

Assim, comunicação se tornou para nós questão de mediações mais do que de meios, questão de cultura e, portanto, não só conhecimento, mas de reconhecimento. Um reconhecimento que foi de início, uma operação de deslocamento metodológico para rever o processo inteiro da comunicação a partir de seu outro lado, o da recepção, o das resistências que aí tem seu lugar, o da apropriação a partir de seus usos (MARTíN-BARBERO, 2006, p. 28).

Com a teoria das mediações, entre outros aspectos, os estudos culturais se preocupam com as diversas relações estabelecidas pelos processos comunicativos para compreender as apropriações e os usos que a audiência faz com a mensagem que recebe. Dessa forma, a partir dos estudos culturais e de recepção, busca-se compreender o processo de audição radiofônica em Vila Brasil, apropriando-se, principalmente, da experiência vivenciada pela comunidade sobre a alfabetização de adultos, por meio das aulas radiofônicas do MEB. 


\title{
CAMINHOS DA PESQUISA
}

A pesquisa seguiu inspiração do método da recepção e o enfoque preferencial foi o qualitativo, considerando a adequação na busca de entender o processo comunicativo sobre a audição radiofônica em uma comunidade rural na Amazônia paraense. "Com o enfoque qualitativo o pesquisador procura reduzir a distância entre a teoria e os dados, entre 0 contexto e a ação, usando a lógica da análise fenomenológica, isto é, da compreensão dos fenômenos pela sua descrição e interpretação" (TEIXEIRA, 2005, p. 137). Além disso, de acordo com Lakatos e Marconi, a pesquisa qualitativa tem a seguinte definição:

\begin{abstract}
A interpretação dos fenômenos e a atribuição de significados são básicas no processo de pesquisa qualitativa. Não requer o uso de métodos e técnicas estatísticas. O ambiente natural é a fonte direta para coleta de dados e o pesquisador é o instrumento-chave. É descritiva. Os pesquisadores tendem a analisar seus dados indutivamente. O processo e seu significado são os focos principais de abordagem (LAKATOS e MARCONI, 2010, p. 237).
\end{abstract}

Considerando a pesquisa de campo da dissertação que deu origem a este artigo, os moradores de Vila Brasil, em 2013, de acordo com os relatórios da Agente Comunitária de Saúde (ACS) que atende a comunidade, são distribuídos em faixas etárias que vão de 0 a 11 anos, com 110 crianças; de 12 a 24 anos, com 95 jovens; de 25 a 59 anos, com 89 adultos, e a partir de 60 anos, com 35 idosos, totalizando 329 pessoas que moram na comunidade. Em se tratando de gênero, são 153 mulheres e 176 homens. A pesquisa, no entanto, aqui neste artigo trabalhou com a faixa etária a partir de 60 anos de idade.

Como parte dos procedimentos metodológicos, na fase da pesquisa exploratória foi aplicado um questionário com perguntas abertas e fechadas a 35 moradores, o que corresponde a $15,98 \%$ de uma população de 219 moradores. Sobre as perguntas abertas, Lakatos e Marconi (2010, p. 187) observam que "permitem ao informante responder livremente, usando linguagem própria e emitir opiniões", enquanto que as perguntas fechadas 
"são aquelas que o informante escolhe sua resposta entre duas opções: sim e não".

Foram realizadas, no total, 35 entrevistas com os moradores radiouvintes, distribuídas da seguinte forma, de acordo com os tópicos: sobre o MEB foram realizadas sete entrevistas para tratar das escolas radiofônicas, com ex-alunos, ex-monitores em Vila Brasil e com uma das ex-coordenadora da entidade, em Santarém, nos meses de agosto, setembro e outubro de 2013, em cinco residências da comunidade, para acompanhar a audição radiofônica junto aos moradores de Vila Brasil.

\section{RESULTADOS: apresentação e discussão}

A escola radiofônica do Movimento de Educação de Base (MEB), realizada a partir de 1968, em Vila Brasil, foi uma das primeiras experiências de audição por meio do rádio na comunidade e que teve a efetiva participação dos moradores interessados no projeto de alfabetização de adultos.

Antes do MEB, no Brasil, já havia outras experiências de utilizar o rádio como suporte de comunicação para alfabetizar adultos: o Movimento de Cultura Popular (MCP), o Centro Popular de Cultura (CPC), a Campanha de Educação Popular (CEPLAR) e, depois do Regime Militar, o Movimento Brasileiro de Alfabetização (MOBRAL) e o Projeto Minerva.

A Entrevistada 19, 72-F, natural da comunidade de São Benedito do Ituqui, atuou no MEB como professora das aulas radiofônicas, em Santarém, no Pará, no período de 1967 a 1972 e coordenou a entidade no período de 1974 a 1985. Segundo ela, em Santarém, O MEB passou a operar em 1966, por iniciativa do Bispo Dom Tiago Ryan, dois anos depois da implantação da Rádio Educadora, que mais tarde passou a ser denominada Rádio Rural de Santarém AM.

De acordo com a Entrevistada 19, 72-F, o MEB era um movimento de educação de Base. Para ela, educação de base é o mínimo necessário para se considerar uma pessoa com dignidade humana. $O$ programa do MEB consistia em ler, escrever (alfabetizar), inclusive, o trabalho de 
conscientização das pessoas, a partir dos elementos de reflexão dados a ele: saúde, alimentação, higiene, socialização, cooperação, espiritualidade e valorização cultural. A proposta era que o modelo de educação do MEB contribuísse com o desenvolvimento em todas as dimensões da vida do homem. A fundamentação desse ensino era a prática do Evangelho.

A mesma Entrevistada 19, 72-F destaca que o principal objetivo do projeto era trabalhar a educação integral do homem, que ia desde os hábitos alimentares, até o uso correto do papel higiênico, uma novidade aos moradores das comunidades rurais, utilizando como suporte o rádio e as visitas às comunidades. Além disso, estavam alinhados com as orientações da Organização das Nações Unidas para a Educação, Ciência e Cultura (UNESCO), que defendia a educação de base:

Criada em 1947, a entidade estimula programas nacionais de educação de adultos para regiões "atrasadas", visando à formação de atitudes e transmissão de conhecimentos. Além de aprender a ler, escrever, falar, ouvir, contar, os alunos teriam informações sobre agricultura, trabalhos caseiros, formação técnica para ofícios, noções de higiene, entre outras, para o progresso econômico (FAVERO, 2006, p.22).

Eram 460 comunidades rurais que integravam o projeto das escolas radiofônicas do MEB, com quatro mil alunos na alfabetização e seis mil na educação geral, totalizando 10 mil alunos matriculados, nas áreas de abrangência da Diocese - os municípios de Santarém, Prainha, Monte Alegre e Alenquer, na região oeste do Estado do Pará. A rede de escolas radiofônicas funcionava como uma imensa sala de aula com 10 mil alunos estudando, praticamente, ao mesmo tempo, incluindo as quatro cidades, com uma hora de aula para cada um dos ciclos ou séries. O programa também contava com uma considerável audiência na cidade, com alunos participando das aulas.

Entre as comunidades que resolveram abrir uma escola radiofônica estava Vila Brasil, no baixo Arapiuns, em 1968. Iniciou com alfabetização de adultos e depois foram implantadas outras séries de acordo com a evolução 
das primeiras turmas. No prazo de cinco anos, O MEB, em Vila Brasil, mantinha seis turmas, que iam da alfabetização a $5^{a}$ série.

As aulas radiofônicas em Santarém, no que se refere à parte educativa, iniciaram de forma gradual, por meio de cartilhas, confeccionada pelo Estado. Com o advento da metodologia de Paulo Freire, O MEB passou a trabalhar com 18 cartazes, contendo todas as sílabas ou sons, fonemas existentes no alfabeto. Trabalhava com 18 palavras-chave que dessem conta do alfabeto e de forte teor pragmático, um cartaz, uma gravura e uma palavra. Utilizava-se sobre o cartaz uma tarja para que os alunos tentassem interpretar a palavra, como "povo", por exemplo. Quando todos os alunos entendiam o sentido da representação do objeto, só depois a palavra era estudada como forma de sílabas.

A educadora radiofônica questiona: - qual era o sentido de conscientização? Ela mesma explica que a palavra "tijolo" era discutida em suas diversas dimensões e profundidade, refletindo como o produto foi feito, quem havia feito quanto às pessoas ganhavam para fazer o tijolo; e se discutiam as relações de trabalho, se o preço pago era justo, as condições de trabalho das pessoas e outros - ao contrário do Mobral que não aprofundava as discussões, embora refletisse de que o tijolo era feito, mas não discutia a relação de trabalho, como o MEB fazia.

Além desses fundamentos, eram aplicadas as disciplinas convencionais, para dar conta do conteúdo programático, tais como: Língua Portuguesa, Matemática, Geografia, História e Ciências. As aulas funcionavam em conformidade com o calendário oficial do município, de acordo com a Lei de Diretrizes e Bases da Educação da época. As aulas iam de março a junho e de agosto a novembro de cada ano.

Não se pode, no entanto, concluir sobre as escolas radiofônicas do MEB, em Vila Brasil, sem destacar, minimamente, a Feira da Cultura Popular, um dos projetos que desenvolveu papel de animação, organização e integração das comunidades rurais. A Entrevistada 19, 72-F afirma que a primeira Feira da Cultura Popular (FCP) aconteceu em setembro de 1969, dirigida pela Coordenadora do MEB, professora leda Campos, evento 
realizado na esquina da Travessa dos Mártires com São Sebastião, onde atualmente (2013) está instalada a TV Encontro - Canal 26, em Santarém.

O projeto surgiu com o objetivo de difundir e valorizar a Cultura e a Arte popular, integrando o homem da cidade e do interior no processo de desenvolvimento regional, destacando e incentivando o potencial da cultura, da criatividade por meio de um evento e dentro de um princípio da fraternidade, idealizado por Dom Tiago Ryan e pelas professoras Francisca Carvalho do Rosário, leda Campos e Aurenice Araújo.

No período de 1969 a 1972, o projeto ocorreu anualmente. Depois foi realizado em 1975, 1977, 1978, 1980, 1981 e 1982. Até 1982, todas as feiras foram coordenadas pelo MEB. Na época, a coordenação conseguiu mobilizar a participação de até 117 comunidades, por edição. A partir de 1985, com a extinção do MEB, o projeto de Feira da Cultura Popular deixou de ser realizado por 16 anos. Foi resgatado em 2001 pela Prefeitura Municipal de Santarém e passou a ser realizado anualmente, até 2012.

Aqui, porém, será discutida a manifestação cultural como resultado das estratégias da programação radiofônica, produzidas pela Rádio Rural de Santarém AM a fim de incentivar a educação nas comunidades rurais da Amazônia, envolvendo a comunicação e a cultura, e compreender a ressonância das emissões do rádio junto ao ouvinte.

Durante o período de pesquisa realizada em Vila Brasil, constatou-se que algumas pessoas que participaram da escola radiofônica ainda vivem na comunidade. São homens e mulheres que se tornaram pais de família. Percebe-se que muitos aprenderam a assinar seus nomes com os professores do MEB, ouvindo e participando das aulas pelo rádio. É o caso dos personagens em destaque neste artigo, que vão revelar por que o rádio se tornou tão importante no cotidiano de Vila Brasil.

A Entrevistada 20, 63-F, natural de Vila Brasil, estudou pela escola radiofônica do MEB, em 1968. Declarou que os alunos se reuniam no barracão da comunidade para acompanhar e participar das aulas, que 
eram transmitidas no período da noite, no horário das $19 \mathrm{~h}$ às $21 \mathrm{~h}$, com audição organizada, na presença de um monitor7.

A Entrevistada 20, 63-F lembrou ainda que a turma era formada por 18 alunos, mas só recordou da Dorinha, Ireno, Aluísio, Ico, Diva, Neca e Dico. O monitor naquele ano era Braz Dias Cruz que recebia treinamento em Santarém com as professoras do MEB. De acordo com a Entrevistada 20, 63F, ele era uma pessoa muito importante na comunidade devido ao grau de conhecimento que tinha, embora não tivesse muito estudo. Mas as orientações que recebia em Santarém eram suficientes para ajudar as turmas das escolas radiofônicas.

A Entrevistada 21, 63-F estudou até a $2^{a}$ série do antigo primário pela escola radiofônica do MEB e mais dois anos na escola normal, depois que chegou uma unidade escolar para atender Vila Brasil.

O Entrevistado 22, 57-M foi aluno da escola radiofônica do MEB, em 1974, em Vila Brasil. Ele afirmou que os encontros eram realizados na sede da comunidade, local que depois foi transformado em uma escola normal. Para ele, o rádio é fonte de conhecimento. A definição tem base no que aconteceu no passado, quando o rádio era considerado professor.

Para o entrevistado, foi através do rádio que conseguiu conquistar um pouco do conhecimento, que veio através do programa radiofônico educativo do MEB. A partir desse momento aprendeu valorizar ainda mais o rádio e hoje o vê como um veículo de informação e de educação, principalmente, às pessoas que participaram das aulas radiofônicas.

A Entrevistada 23, 68-F mora em Vila Brasil desde 1968. Ela também teve como instituição de estudo a escola radiofônica do MEB. Recorda que a coordenadora da época era a professora Aurenice Araújo e destaca como as aulas eram organizadas: o programa radiofônico era transmitido pela Rádio Rural de Santarém, apresentado por uma professora no início da noite. O programa tinha como conteúdo disciplinas de Língua Portuguesa,

\footnotetext{
7 O monitor era um tipo de mediador em sala de aula. Ele recebia treinamento em Santarém para estimular os alunos a participarem das aulas e dos debates após a irradiação da professora que se encontrava no estúdio da Rádio Rural, em Santarém (ENTREVISTADA 21, 63-F).
} 
Matemática, História, Geografia e Ciências. Na comunidade os alunos e monitores se reuniam em um local apropriado. Geralmente havia uma mesa grande que comportasse alunos e monitores que juntos ouviam o rádio e faziam suas anotações. Os exercícios eram orientados com base nos cartazes e nas cartilhas que o MEB confeccionava para dar apoio aos alunos e monitores na comunidade.

O Entrevistado 24, 74-M declarou que a participação dele nas aulas radiofônicas do MEB foi em 1974, com 26 anos de idade. Ele estudou até a $5^{a}$ série. Para ele, o rádio é muito importante devido transmitir as orientações de diversos modos, como ocorreu com as aulas radiofônicas. "Além disso, o rádio ajuda as pessoas do interior na orientação das famílias e, com isso, os pais têm maiores informações para orientar os seus filhos".

Esse trabalho era realizado por pessoas simples da comunidade, mas dedicadas e comprometidas. Manuel Justino Sarmento é uma das lideranças bastante lembrada, devido ao dinamismo dele junto à comunidade. Foi assim que O MEB conseguiu bons resultados em grande maioria das comunidades, isto é, onde pode contar com o dinamismo particular dos monitores. Os monitores funcionavam como auxiliares do educador radiofônico, que se encontrava nos estúdios de rádio, distante dos locais de realização das aulas, como constata Baumworcel (2008).

Perante a técnica de não-diretividade de alguns e a doutrinação de outros, vários monitores conseguiram estimular uma relação de diálogo no processo de ensino-aprendizagem em algumas escolas radiofônicas. E acreditamos que foi a interlocução deste tipo de monitor-líder, treinado pelos coordenadores do MEB para organizar a participação dos alunos, o maior diferencial desta experiência de educação e conscientização pelo rádio (BAUMWORCEL, 2008, p. 12).

Em Vila Brasil, no período em que o MEB atuou, foi estimulado às realizações dos puxiruns, organizados com a participação de homens e mulheres. Os homens faziam os trabalhos mais pesados e as mulheres faziam as atividades leves, além de preparar a alimentação, como o tarubá ${ }^{8}$, a

\footnotetext{
${ }^{8}$ Bebida fermentada feita de beiju-açu dissolvido em água (FERREIRA, 1999).
} 
tiborna (bebida que substitui a cachaça) e o almoço de todos os participantes.

\begin{abstract}
"Ler, escrever e interpretar textos com situações e vocabulários próprios das áreas rurais", "distinguir as relações entre as estruturas sociais, econômicas, políticas e religiosas", "saber utilizar a legislação e as potencialidades econômicas da comunidade" e "desenvolver o conhecimento sobre as técnicas de trabalho em grupo" eram alguns - entre os muitos - pontos básicos divulgados pela programação do MEB. O incentivo a essa prática de conscientização serviu como apoio para a introdução, nos programas educativos, da ideia de animação popular (MOREIRA, 1991, p. 20-21).
\end{abstract}

O projeto de alfabetização de adultos foi desenvolvido nas regiões mais pobres do Brasil. Nos primeiros treinamentos, os professores do MEB vivenciaram certas experiências de pessoas que não tinham o hábito de trocar as meias e outras roupas por falta de costume e por carência.

O Movimento de Educação de Base (MEB) concentrou sua atuação em regiões brasileiras consideradas subdesenvolvidas - Norte, Nordeste e Centro-Oeste - e imprimiu uma característica adicional ao ensino radiofônico: Além da alfabetização, as escolas também cuidavam da conscientização, da mudança de atitudes e da instrumentação das comunidades receptoras dos programas elaborados pelo Movimento (MOREIRA, 1991, p. 20).

Neste artigo que destaca as ações do MEB em Vila Brasil, percebe-se que a escola radiofônica é uma das principais experiências da comunidade sobre a recepção/audição. O recorte histórico tem a ver com a mudança de comportamento dos comunitários em relação ao hábito e à cultura. Alunos e monitores sentiam-se obrigados, pelo menos, inicialmente, em parar para ouvir o rádio de forma organizada, concentrada. De acordo com Mantín-Barbero (2006), trata-se de uma redefinição de sentido que tem reflexos profundos, entre outros, na cultura da comunidade.

Abre-se assim ao debate um novo horizonte de problemas, no qual estão redefinidos os sentidos tanto da cultura quanto da política, e do qual a problemática da comunicação não participa apenas a título temático e quantitativo - os enormes interesses econômicos que movem as empresas de comunicação - mas também qualitativo: na redefinição da cultura, é fundamental a compreensão de sua natureza comunicativa. Isto é, seu caráter de processo produtor de significações e não de mera circulação de informações, no qual o receptor, portanto, não é um simples

Revista Exitus, Santarém/PA, Vol. 9, № 1, p. 340 - 366, JAN/MAR 2019. 
decodificador daquilo que o emissor depositou na mensagem, mas também um produtor (MARTíN-BARBERO, 2006, p. 289).

Depois da escola radiofônica do MEB, a comunidade de Vila Brasil foi influenciada, profundamente, por uma cultura externa. Uma cultura educacional híbrida, proveniente de uma realidade urbana, ou a partir de Belém e Manaus ou do eixo Rio/São Paulo. Pois, inicialmente, as cartilhas que serviam de base às aulas radiofônicas do MEB eram confeccionadas nas regiões Sul e Centro-Oeste do Brasil.

Os monitores recebiam as orientações de acordo com os conteúdos repassados por essas cartilhas e, depois, alunos do MEB se tornaram professores em suas comunidades, fazendo usos das mensagens que thes foram repassadas durante as aulas. Pode-se constatar que há um processo de interação e apropriação por meio de relatos, a exemplo deste: "Foi o rádio que me proporcionou ser o que me tornei na minha comunidade e foi através dele que consegui ajudar muita gente" (Entrevistado 27, 83-M).

As regiões Norte e Nordeste, na década de 1960, apresentavam os maiores índices de analfabetismo. Constata-se também que, apesar das boas intenções do MEB de utilizar o rádio para alfabetizar as pessoas, o modelo de comunicação estabelecido foi unidirecional e voltado às massas. De acordo com Canclini (2008), no século XX, os meios de comunicação (rádio e televisão) tinham essa compreensão.

Em meados do século falava-se em cultura de massa, ainda que logo tenha percebido e que os novos meios de comunicação, como o rádio e a televisão, não eram propriedades das massas. Parecia mais justo 361 diê-la cultura para a massa, mas essa designação durou enquanto pôde ser sustentada a visão unidirecional da comunicação que acreditava na manipulação absoluta dos meios e supunha que suas mensagens eram destinadas às massas, receptoras submissas (CANCLINI, 2008, p. 257).

As escolas radiofônicas do MEB tinham essas características, tanto que recebia críticas de Paulo Freire, que denominava de "educação saci" (BAUMWORCEL, 2008, p.2). Para Freire as aulas radiofônicas tinham apenas uma perna de ida. A partir dessa crítica, compreende-se que não havia 
interação nem feedback, portanto não havia comunicação. Ou seja, os alunos do MEB seriam como recipientes vazios, não interagiam com os professores que se encontravam na cidade, dentro de um estúdio de rádio. Aos alunos, bastava receber as informações das aulas radiofônicas, de forma passiva e submissa, mesmo que a proposta da UNESCO fosse contribuir para a formação do homem integral.

Outra discussão sobre as escolas radiofônicas do MEB trata da função que o rádio assumiu nas décadas de 1960, 1970 e 1980. O rádio ganhou um impulso relevante no mercado brasileiro, além disso, assumiu o lugar de milhares de professores. Por meio do rádio, apenas um professor conseguia ministrar aula a centenas de pessoas. Em Santarém, em duas horas de aula a professora Aurenice Araújo conseguia atender dez mil alunos.

Apesar do interesse regionalizado dos coordenadores do MEB em ter respostas sobre os usos e as apropriações dos ex-alunos em relação à educação que receberam com as aulas radiofônicas, não se conhece avaliações em nível nacional em busca dos resultados atingidos pelo projeto. Certamente, o projeto na época foi uma das iniciavas inovadoras que serviram para alimentar a esperança de quem sonhou com um Brasil melhor e menos desigual.

A experiência de audição radiofônica dos ex-alunos do MEB, em Vila Brasil, nos anos de 1970, difere do conceito de recepção. Para Orozco (2001), a recepção não pode ser entendida como o recebimento da mensagem:

Consecuentemente, "recepción" no puede entenderse como mero recibimiento, sino como ver interacción, siempre mediada desde diversas fuentes y contextualizada material, cognitiva $y$ emocionalmente, que se despliega a lo largo de ver 362udiênci complejo situado ver 362udiên escenarios y que incluye 362 udiências362 y negociaciones de los sujetos ver el referente mediático de la que resultan apropiaciones variadas que van desde la mera reproducción hasta la 362udiências362 y la contestación (OROZCO, 2001, p. 23)'.

\footnotetext{
${ }^{9}$ Consequentemente, "recepção" não pode ser entendida como mera hospedagem, mas como uma interação, sempre mediada a partir de várias fontes e materiais contextuais, cognitivamente e emocionalmente, que se desenrola ao longo de um complexo localizado em vários cenários e inclui estratégias e negociações indivíduais com os meios de
} 
Não havia interação instantânea, um dos itens básicos do processo comunicativo, pois os professores que irradiavam os programas do MEB não tinham retorno imediato sobre a mensagem emitida aos alunos e monitores. A pesquisa mostrou que os professores do MEB recebiam cartas com as dúvidas dos alunos, no prazo de uma ou duas semanas depois da emissão dos programas.

Em síntese, para entender melhor o rádio no cotidiano dos moradores de Vila Brasil, precisa-se admitir que as mudanças ocorridas nos últimos anos no mundo inteiro também atingiram os meios rural e urbano da Amazônia. A partir dessa compreensão, percebe-se que os radiouvintes de Vila Brasil ressignificaram o rádio, utilizando-o de outras formas, a exemplo do que ocorre todos os meses, na comunidade, quando aposentados e famílias contempladas pelos programas sociais do Governo Federal só se deslocam para a cidade depois de informados que o banco está pagando os seus benefícios.

Além disso, os professores estão utilizando às informações radiofônicas, em espacial as notícias mais importantes da localidade, como pautas para assuntos transversais discutidos em sala da aula, muitos desses temas não previstos na grade curricular convencional. Com isso, eles conseguem debater situações que fazem parte da realidade do lugar e que têm relação com o cotidiano dos alunos de Vila Brasil.

\section{CONSIDERAÇÕES FINAIS}

O estudo proposto neste artigo, ao dialogar com os conceitos e teorias sobre o processo comunicativo, aproximou este autor dos primeiros estudos sobre recepção, teorias, conceitos e contextos, o que lhe garantiu desbravar um caminho ora escorregadio, ora sólido para discorrer sobre a audição radiofônica em uma comunidade na Amazônia paraense.

Percebeu-se que o percurso histórico e cultural de Vila Brasil é povoado pela influência do rádio desde a sua origem. As escolas 
radiofônicas do Movimento de Educação de Base (MEB) são exemplo disso. As pessoas, ao ouvirem os programas, recebiam conhecimento por meio das disciplinas de História, Geografia, Língua Portuguesa, Matemática, ensino religioso e, posteriormente, o certificado de conclusão do curso, por meio da audição e recepção, o que caracteriza os estudos culturais e de recepção, mas também de usos e gratificações.

Constatou-se que a organização social da comunidade é formada por família, agricultores, pescadores, professores, aposentados e estudantes. A família, no entanto, continua sendo o espaço mais apropriado, onde se manifestam os três lugares de audição: a cotidianidade familiar, a temporalidade social e a competência cultural, de acordo com MartínBarbero (2006).

Verificou-se que o rádio é o meio de comunicação presente desde a fundação da comunidade, atravessando todos os percursos. Esse meio de transmissão ajudou na construção do que se tornou Vila Brasil na atualidade (2013), com uma cultura sedimentada, passando por gerações, cada dia fortalecendo ainda mais a cultura de ouvir o rádio.

Este estudo mostra que o rádio ainda está presente no cotidiano de Vila Brasil, influenciando a realidade social da comunidade e ajudando as instituições na condução de suas políticas, em termos de orientação. Constata-se, também, que o rádio começou a perder espaço para outras mediações como a televisão e o celular. Além disso, as pessoas deixaram o hábito de levar o rádio ao roçado e à pescaria, porque os rádios à pilha estão sendo substituídos por aparelhos à energia elétrica. Enfim, o rádio mantém a sua importância no cotidiano dos moradores de Vila Brasil, mas, sem a preponderância do passado.

Espera-se, portanto, que este estudo possa contribuir para estimular o surgimento de novas pesquisas em comunicação sobre o rádio na Amazônia e ajude a entender melhor o seu papel no processo de organização social e comunicativo das comunidades rurais e urbanas dessa imensa região. 


\section{REFERÊNCIAS}

ADAMS, C.; MURRIETA, R.; NEVES, W. (Org.). Sociedades caboclas amazônicas: modernidade e invisibilidade. 1 ed. São Paulo: Annablume, 2006.

BAUMWORCEL, A. As escolas radiofônicas do MEB. ENCONTRO NACIONAL DA REDE ALFREDO DE CARVALHO, 6., 2008, Niterói. Anais... Disponível em: < http://www.ufrgs.br/alcar/encontros-nacionais-1/encontros-nacionais/6 ${ }^{\circ}$ encontro-2008-1/As\%20escolas\%20radiofonicas\%20do\%20MEB.pdf>: Acesso em: 22 mar. 2015.

CANCLINI, N. G. Culturas híbridas: estratégias para entrar e sair da modernidade. 4 ed. 3 reimpr. São Paulo: Editora da Universidade de São Paulo, 2008.

CANCLINI, N. G. El consumo cultural y su estudio en México: una propuesta teórica. México: CNCA, 1993.

CASTELLS, M. A era da informação: economia, sociedade e cultura. A sociedade em rede. São Paulo: Paz e Terra. 1999.

ESCOSTEGUY, A. C. e JACKS, N. Comunicação e recepção. São Paulo: Hacker Editores, 2005.

FAVERO, O. Uma pedagogia da participação popular: análise da prática educativa do MEB (1961/1966). Campinas: Autores Associados, 2006.

FERREIRA, A. B. de H. Novo Aurélio Século XXI: o dicionário da língua portuguesa. 3 ed. Totalmente ver. E ampl. Rio de Janeiro: Nova Fronteira, 1999.

FERREIRA, P. R. Após o regatão, o rádio e a televisão. 2009. Disponível em: <http://www.redealcar.jornalismo.ufsc.br/>._Acesso em: 20 mar. 2014.

FERREIRA, A. B. de H. Novo Dicionário Básico da Língua Portuguesa. São Paulo. Folha de São Paulo, 1995, p. 1577.

IBGE. Censo demográfico 2017. Disponível em:

<http://cidades.ibge.gov.br/xtras/perfil.php?lang=\&codmun=150680\&search =para $\mid$ santarem>. Acesso em: 29 jul. 2017.

IORIS, E. M. Identidades negadas, identidades construídas: processos identitários e conflitos territoriais na Amazônia. Universidade Federal de Santa Catarina: Florianópolis, 2005.

LAKATOS, E. M. MARCONI, M. de A. Fundamentos de metodologia científica. 7. Ed. São Paulo: Atlas, 2010. 
LOPES, M. I. V. Estratégias metodológicas da pesquisa de recepção.

INTERCOM - Revista Brasileira de Comunicação, Vol. XVI, n. 2, São Paulo, 1993.

MARTÍN-BARBERO, J. Dos meios as mediações: comunicação, cultura e hegemonia. Rio de Janeiro: Ed. UFRJ, 2006.

MOREIRA, S. V. O rádio no Brasil. Rio de Janeiro: Rio Fundo, 1991.

MOREIRA, S. V. Rádio Palanque. Rio de Janeiro: Mil Palavras, 1998.

OROZCO, G. G. Televisión, 366udiências y educación. Colombia: Grupo Editorial Norma, 2001.

RODRIGUES, M. E. Recepção radiofônica: a etnocenodramaturgia noticiosa no rádio, na comunidade rural de São Benedito de Ituqui, em Santarém Pará. 2013, 120f, (Monografia-especialização em Jornalismo Científico) UFOPA, Santarém-PA.

ROSENDHAL, Z. Matrizes da geografia cultural. Rio de Janeiro. Ed. UERJ. 2001.

SANTOS, B. de S. Um discurso sobre as ciências. 16. Ed. Porto: Afrontamento, 2010.

SOUSA, M. W. de (Org.). Sujeito, o lado oculto do receptor. São Paulo: Brasiliense, 1995.

TEIXEIRA, E. As três metodologias: a acadêmica, da ciência e da pesquisa. Petrópolis: Vozes, 2005.

Recebido em: 02 de abril de 2018 Aprovado em: 12 de setembro de 2018 